\title{
Susceptibility of Blastomyces dermatitidis Strains to Products of Oxidative Metabolism
}

\author{
ALAN M. SUGAR, RESHAM S. CHAHAL, ELMER BRUMMER, AND DAVID A. STEVENS* \\ Division of Infectious Diseases, Department of Medicine, Santa Clara Valley Medical Center, ${ }^{*}$ and Institute \\ for Medical Research, San Jose, California 95128, and Stanford University Medical School, Stanford, \\ California 94305
}

Received 11 April 1983/Accepted 31 May 1983

\begin{abstract}
Three strains of Blastomyces dermatitidis which differ in their virulence for mice were exposed in their yeast form to various components of the peroxidasehydrogen peroxide-halide system. Susceptibility to $\mathrm{H}_{2} \mathrm{O}_{2}$ alone correlated with virulence, with the most virulent strain (ATCC 26199) least susceptible (50\% lethal dose, $>50 \mathrm{mM}$ ) and an avirulent strain (ATCC 26197) most susceptible (50\% lethal dose $<3.3 \mathrm{mM}$ ). A strain of intermediate virulence (ATCC 26198) was of intermediate susceptibility ( $50 \%$ lethal dose, $11.5 \mathrm{mM}$ ). The addition of a nontoxic concentration of $\mathrm{KI}\left(5 \times 10^{-4} \mathrm{M}\right)$ did not increase $\mathrm{H}_{2} \mathrm{O}_{2}$ toxicity. However, the addition of either myeloperoxidase or horseradish peroxidase and $\mathrm{KI}$ markedly decreased the amount of $\mathrm{H}_{2} \mathrm{O}_{2}$ required to kill the organisms, with $100 \pm 0 \%$ of all strains killed at $5 \times 10^{-5} \mathrm{M} \mathrm{H}_{2} \mathrm{O}_{2}$ and $97 \pm 4,100 \pm 0$, and $94 \pm 8 \%$ of ATCC 26199, ATCC 26198, and ATCC 26197 killed, respectively, at $5 \times 10^{-6} \mathrm{M} \mathrm{H}_{2} \mathrm{O}_{2}$. Kinetic studies with $\mathrm{H}_{2} \mathrm{O}_{2}$ alone revealed a delayed onset of killing, but virtually $100 \%$ of organisms were killed by $120 \mathrm{~min}$ of exposure in all strains. By comparison, the peroxidase-hydrogen peroxide-halide system was $100 \%$ lethal for all strains at $1 \mathrm{~min}$. The relatively high concentrations of $\mathrm{H}_{2} \mathrm{O}_{2}$ required to kill the yeast phase of $B$. dermatitidis suggest that $\mathrm{H}_{2} \mathrm{O}_{2}$ alone does not account for host resistance to the organism. However, the rapidly lethal effect of the peroxidasehydrogen peroxide-halide system at physiologically relevant concentrations suggests that this may be one mechanism of host defense to $B$. dermatitidis.
\end{abstract}

Products of oxidative metabolism are microbicidal and presumably constitute an important microbicidal system in phagocytic cells (11). In particular, the peroxidase-hydrogen peroxidehalide (PPH) system is effective in the killing of bacteria $(10,16)$, fungi $(7,9)$, protozoa $(13,14)$, and tumor cells (17). With the fungi, attention has been paid to Candida species, which are opportunistic pathogens $(7,12)$. However, there are scant data regarding the interaction of this system with the dimorphic fungi responsible for the endemic mycoses, which are principally diseases of normal hosts (9). Susceptibility to oxidative systems has been reported with Histoplasma capsulatum (9).

In previous studies, we reported that peritoneal macrophages activated by Mycobacterium bovis BCG or concanavalin A, in contrast to resident macrophages, killed the yeast phase of Blastomyces dermatitidis during a 4-h cocultivation (4). We therefore studied whether the interaction of this organism with products of the PPH system could be a possible mechanism for killing by activated macrophages. We used three strains of $B$. dermatitidis which vary in their virulence, as studied in a murine model $(1,2)$. The results of the present study, the first to report the interaction of products of oxidative metabolism with $B$. dermatitidis, show that the three strains exhibit differences in susceptibility to $\mathrm{H}_{2} \mathrm{O}_{2}$ and to products of the PPH system.

\section{MATERIALS AND METHODS}

Fungi. Three strains of $\boldsymbol{B}$. dermatitidis were maintained on Sabouraud dextrose agar slants at $4^{\circ} \mathrm{C}$. They were subcultured, with no more than 15 transfers, into $3 \mathrm{ml}$ of a synthetic medium (8). The organisms were subcultured in all experiments during the log phase of growth, 2 to 3 days before an experiment. The three strains used had previously been defined in terms of virulence for mice: ATCC 26199 (V, virulent), ATCC 26197 (GA-1, avirulent), and ATCC 26198 (KL-1, intermediate in virulence) $(1,2)$.

Chemicals. Hydrogen peroxide was obtained as a reagent-grade $30 \%$ solution (Matheson, Coleman and Bell Manufacturing, Norwood, Ohio). Human myeloperoxidase (MPO; 2,655 U/mg) was the generous gift of Robert I. Lehrer, University of California Medical Center, Los Angeles. Horseradish peroxidase type VI (HPO; 250 to $330 \mathrm{U} / \mathrm{mg}$ ) and catalase (bovine liver; $2,250 \mathrm{U} / \mathrm{mg}$ ) were obtained from Sigma Chemical Co., 
TABLE 1. Percent killing of $B$. dermatitidis by high concentrations of $\mathrm{H}_{2} \mathrm{O}_{2}$

\begin{tabular}{lccr}
\hline \multirow{2}{*}{ Strain } & \multicolumn{3}{c}{ Mean \% killing $\pm \mathrm{SD}$ at $\mathrm{H}_{2} \mathrm{O}_{2}$ concn $(\mathrm{M})$ of: } \\
\cline { 2 - 4 } & $5 \times 10^{-2 a}$ & $5 \times 10^{-3 b}$ & $5 \times 10^{-4}$ \\
\hline V & $45 \pm 6(4)^{c}$ & $10 \pm 13(5)$ & $0(5)$ \\
KL-1 & $97 \pm 3(3)$ & $24 \pm 12(3)$ & $0(3)$ \\
GA-1 & $96 \pm 4(3)$ & $61 \pm 17(4)$ & $0(4)$ \\
\hline
\end{tabular}

${ }^{a}$ Killing of $\mathrm{V}$ versus KL-1 or GA-1, $P<0.001$.

${ }^{b}$ Killing of KL-1 versus GA-1, $P<0.02$; killing of V versus GA-1, $P<0.005$.

$c$ Number of experiments.

St. Louis, Mo. Before use, the catalase was dialyzed against $0.2 \mathrm{M}$ sodium phosphate buffer, $\mathrm{pH} 6.5$, for 24 h. Catalase activity was assayed by the $O$-dianisidine (Sigma) method, using standard techniques (6). Potassium iodide (reagent grade; J. T. Baker Chemical Co., Phillipsburg, N.J.) was prepared as a $1 \mathrm{M}$ stock solution and stored at $4^{\circ} \mathrm{C}$ for no longer than 2 weeks. Sodium phosphate buffer $(0.2 \mathrm{M}, \mathrm{pH} 6.5)$ was utilized in all experiments.

In vitro system. The following protocol was followed in all experiments, in the order of the addition of the components: (i) buffer; (ii) $\mathrm{KI}$ (final concentration, $5 \times$ $10^{-4} \mathrm{M}$ ); (iii) catalase, $400 \mathrm{U}$ in $0.1 \mathrm{ml}$; (iv) $\mathrm{H}_{2} \mathrm{O}_{2}$ in 0.1 $\mathrm{ml}$ (the molar concentrations indicated in the text are the final concentrations in the reaction mixture); (v) $B$. dermatitidis, 10,000 CFU in $0.1 \mathrm{ml}$; (vi) HPO or MPO, $28 \mathrm{U}$ in $0.2 \mathrm{ml}$. The total volume of the reaction mixture $(2.0 \mathrm{ml})$ was contained in plastic tubes $(17$ by $100 \mathrm{~mm}$; no. 2051; Falcon Plastics, Oxnard, Calif.). Tubes were incubated at $37^{\circ} \mathrm{C}$ on a rotary shaker at 250 rpm for $1 \mathrm{~h}$. Incubation was extended to $2 \mathrm{~h}$ for the kinetic experiments.

Statistics. Percent killing was calculated as $\{[(\mathrm{CFU}$ at $t=0)-($ CFU in experimental group)]/[CFU at $t=$ $0]\} \times 100$, where $t=0$ was the time at which the reaction mixture was initially combined. Negative values reflect an increase in CFU. The Student $t$ test was used where indicated.

\section{RESULTS}

$\mathrm{H}_{2} \mathrm{O}_{2}$ susceptibility of three strains of $B$. dermatitidis. $\mathrm{V}$ was significantly less susceptible to $5 \times 10^{-2} \mathrm{M} \mathrm{H}_{2} \mathrm{O}_{2}$ than was KL-1 or GA-1 $(P<$ 0.01 ) (Table 1). At $5 \times 10^{-3} \mathrm{M} \mathrm{H}_{2} \mathrm{O}_{2}$, killing of GA-1 was significantly greater than killing of KL-1 $(P<0.02)$ and V $(P<0.005)$. No killing was observed at $5 \times 10^{-4} \mathrm{M} \mathrm{H}_{2} \mathrm{O}_{2}$ for any of the strains. The $50 \%$ lethal dose for $\mathrm{V}, \mathrm{KL}-1$, and GA-1 was $>0.05,0.01$, and $0.003 \mathrm{M} \mathrm{H}_{2} \mathrm{O}_{2}$, respectively. Thus, in vivo virulence for mice correlated with degree of resistance to $\mathrm{H}_{2} \mathrm{O}_{2}$.

Effect of addition of $\mathrm{KI}$ or $\mathrm{PO}$ to $\mathrm{H}_{2} \mathrm{O}_{2}$. Viability of the strains in buffer alone was good, with no significant decrease noted after the 1-h incubation period: $\mathrm{V}, 4 \pm 3 \%$ standard deviation; KL-1, $-4 \pm 7 \%$; GA-1, $2 \pm 9 \%$. For all three strains, KI $\left(5 \times 10^{-4} \mathrm{M}\right)$ and HPO $(14 \mathrm{U} / \mathrm{ml})$ alone or in combination had no effect on viability (Table 2). The results with MPO were identical to those with HPO; therefore, the data were combined. In addition, $\mathrm{H}_{2} \mathrm{O}_{2}$ plus $\mathrm{KI}$ or $\mathrm{HPO}$ was no more toxic than $\mathrm{H}_{2} \mathrm{O}_{2}$ alone (data not shown).

There were no major differences in susceptibility of the three strains to $\mathrm{H}_{2} \mathrm{O}_{2}$ at any concentration tested when $\mathrm{KI}$ and peroxidase (PO) were present (Table 3). The steep dose-response curve of the lethal effect is readily apparent, with virtually all or none of the organism killed within a 10-fold range. However, close inspection of this critical interval reveals a similarity of $\mathrm{H}_{2} \mathrm{O}_{2}$ concentrations required to kill all three strains (Fig. 1).

Effect of adding catalase. The specificity of the killing of $B$. dermatitidis by the PPH system was demonstrated by the complete abrogation of killing with the addition of catalase $(20 \mathrm{U} / \mathrm{ml})$ to the reaction mixture (Table 4). Heated catalase had no effect on $\mathrm{H}_{2} \mathrm{O}_{2}$-mediated killing of any of the three strains (Table 4).

Evidence of lack of endogenous $\mathrm{H}_{2} \mathrm{O}_{2}$ production by $B$. dermatitidis. Incubation of each of the three strains with KI and HPO would be expected to result in killing in the presence of $\mathrm{H}_{2} \mathrm{O}_{2}$ (Table 3). However, viability of the organisms was unaffected during inoculation with these components (Table 2), suggesting that the yeast form of $B$. dermatitidis does not produce appreciable quantities of $\mathrm{H}_{2} \mathrm{O}_{2}$ under these conditions or that enzymes (such as catalase) present in the organism have degraded any $\mathrm{H}_{2} \mathrm{O}_{2}$ that is produced.

Kinetics of killing by $\mathrm{H}_{2} \mathrm{O}_{2}$ and the PPH system. The data from this set of experiments are presented in Fig. 2. Although no killing of any of the strains was observed at 1 min with $\mathrm{H}_{2} \mathrm{O}_{2}(5 \times$ $10^{-2} \mathrm{M}$ for KL-1 and GA-1; $10^{-1} \mathrm{M}$ for V), a significant degree of killing of KL-1 (49 $\pm 7 \%)$ was observed at $30 \mathrm{~min}(P<0.05$ for $\mathrm{KL}-1$ versus GA-1 or V). Killing of KL-1 increased to $95 \pm 0 \%$ by $60 \mathrm{~min}$, and the other two strains also showed a decrease in viability at this time

TABLE 2. Effect of components of the PPH system $^{a}$ on growth of $B$. dermatitidis

\begin{tabular}{lrrr}
\hline & \multicolumn{3}{c}{ Mean \% growth \pm SD } \\
\cline { 2 - 4 } Strain & KI & HPO or MPO & \multicolumn{1}{c}{ KI + HPO or } \\
& & KI + MPO \\
\hline V & $6 \pm 3(5)^{b}$ & $5 \pm 6(6)$ & $0 \pm 8(9)$ \\
KL-1 & $-7 \pm 2(4)$ & $-3 \pm 9(3)$ & $-2 \pm 3(3)$ \\
GA-1 & $-2 \pm 11(4)$ & $-5 \pm 11(3)$ & $-10 \pm 8(3)$ \\
\hline
\end{tabular}

${ }^{a} \mathrm{KI}, 5 \times 10^{-4} \mathrm{M}$; HPO or MPO, $14 \mathrm{U} / \mathrm{ml}$.

${ }^{b}$ Number of experiments. 
TABLE 3. Percent killing of $B$. dermatitidis by the PPH system ${ }^{a}$

\begin{tabular}{lccccrr}
\hline \multirow{2}{*}{ Strain } & \multicolumn{5}{c}{ Mean \% killing \pm SD at $\mathrm{H}_{2} \mathrm{O}_{2}$ concn (M) of: } \\
\cline { 2 - 7 } & $5 \times 10^{-3}$ & $5 \times 10^{-4}$ & $5 \times 10^{-5}$ & $5 \times 10^{-6}$ & $5 \times 10^{-7}$ & $5 \times 10^{-8}$ \\
\hline V & $98 \pm 3(2)^{b}$ & $100 \pm 0(4)$ & $100 \pm 0(4)$ & $97 \pm 4(14)$ & $0(3)$ & $0(7)$ \\
KL-1 & $93 \pm 3(3)$ & $100 \pm 0(4)$ & $100 \pm 0.6(3)$ & $100 \pm 0.4(5)$ & $0(2)$ & $0(4)$ \\
GA-1 & $100 \pm 0.7(2)$ & $100 \pm 0(2)$ & $100 \pm 0(6)$ & $94 \pm 8(8)$ & $0(8)$ & $0(5)$ \\
\hline
\end{tabular}

${ }^{a} \mathrm{KI}, 5 \times 10^{-4} \mathrm{M}$; HPO as source of PO, $14 \mathrm{U} / \mathrm{ml}$.

${ }^{b}$ Number of experiments.

$(P<0.01$ for $\mathrm{KL}-1$ versus $\mathrm{V} ; \boldsymbol{P}<0.005$ for $\mathrm{KL}-1$ versus GA-1).

It is interesting that $\mathrm{V}$ was affected least by $\mathrm{H}_{2} \mathrm{O}_{2}(46 \pm 14 \%$ at $60 \mathrm{~min})$, even though $\mathrm{H}_{2} \mathrm{O}_{2}$ was present at twice the concentration as compared with that present with KL-1 and GA-1. By $120 \mathrm{~min}$, however, virtually all of the organisms of all three strains were nonviable $(\mathrm{V}, 99 \pm 1 \%$; KL-1, $100 \pm 0 \%$; and GA-1, $100 \pm 0 \%$ ).

In marked contrast was the rapid onset of action of the PPH system against the three strains. At $1 \mathrm{~min}$, the earliest point measured, $100 \%$ killing was observed $\left(\mathrm{H}_{2} \mathrm{O}_{2}, 5 \times 10^{-5} \mathrm{M}\right.$; $\mathrm{KI}, 5 \times 10^{-4} \mathrm{M}$; and $\left.\mathrm{HPO}, 14 \mathrm{U} / \mathrm{ml}\right)$.

\section{DISCUSSION}

This is the first report of the susceptibility of $B$. dermatitidis to the products of oxidative metabolism. The results suggest that in the presence of PO and halide, the concentration of
$\mathrm{H}_{2} \mathrm{O}_{2}$ required to kill this organism is markedly decreased. However, in contrast to the correlation of virulence with susceptibility to $\mathrm{H}_{2} \mathrm{O}_{2}$ alone (Table 1), there was no correlation of virulence with susceptibility to the entire $\mathrm{PPH}$ system (Table 3). The decrease in the amount of $\mathrm{H}_{2} \mathrm{O}_{2}$, when combined with halide and $\mathrm{PO}$, required for lethality is consistent with prior reports of the synergistic effects of these components (11).

The only other dimorphic fungus to be similarly studied has been $H$. capsulatum (9). In that study and similar to the results reported here with $B$. dermatitidis, Howard found that blastospores of the fungus are susceptible to high concentrations of $\mathrm{H}_{2} \mathrm{O}_{2}\left(>10^{-4} \mathrm{M}\right)$. This lethal effect was increased by the addition of halide, an observation not noted in the present study with $B$. dermatitidis. An even more substantial lethal effect was noted when MPO was added to the $\mathrm{H}_{2} \mathrm{O}_{2}$-halide system. $\mathrm{KI}$ was a much more effec-

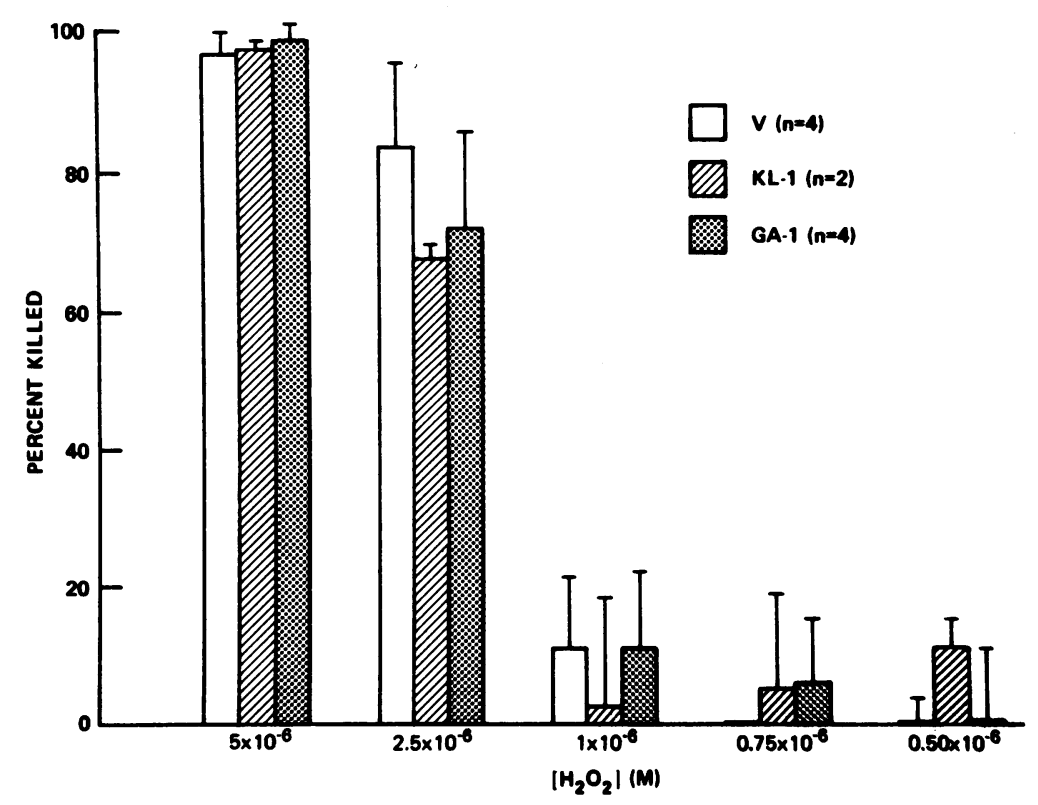

FIG. 1. Percent killing of $B$. dermatitidis by $\mathrm{H}_{2} \mathrm{O}_{2}$ in the presence of $\mathrm{HPO}(14 \mathrm{U} / \mathrm{ml})$ and $\mathrm{KI}\left(5 \times 10^{-4} \mathrm{M}\right)$. Bars represent standard deviation. $n$, Number of experiments. 
TABLE 4. Effect of catalase on killing by HPO-KI$\mathrm{H}_{2} \mathrm{O}_{2}$ system $^{a}$

\begin{tabular}{lccc}
\hline Strain & $\begin{array}{c}\text { Without } \\
\text { catalase }\end{array}$ & $\begin{array}{c}\text { With } \\
\text { catalase }\end{array}$ & $\begin{array}{c}\text { With heated }^{b} \\
\text { catalase }\end{array}$ \\
\hline V & $98 \pm 4(9)^{c}$ & $0(4)$ & $94(1)$ \\
KL-1 & $100 \pm 0.6(3)$ & $0(3)$ & $100(2)$ \\
GA-1 & $100 \pm 0(4)$ & $0(2)$ & $100(2)$ \\
\hline
\end{tabular}

${ }^{a}$ Data are expressed as percentage of $B$. dermatitidis killed \pm standard deviation. $\mathrm{H}_{2} \mathrm{O}_{2}$ at $5 \times 10^{-6} \mathrm{M}$ for $\mathrm{V}$ and $5 \times 10^{-5} \mathrm{M}$ for KL-1 or GA-1; catalase at 20 $\mathrm{U} / \mathrm{ml}$.

${ }^{b}$ Catalase was autoclaved at $121^{\circ} \mathrm{C}$ for $30 \mathrm{~min}$.

${ }^{c}$ Number of experiments.

tive component, in combination with $\mathrm{H}_{2} \mathrm{O}_{2}$ and $\mathrm{HPO}$, than $\mathrm{KCl}$ in damaging $H$. capsulatum. Preliminary experiments show a similar increased lethal effect of $\mathrm{KI}$ over $\mathrm{KCl}$, in combination with $\mathrm{H}_{2} \mathrm{O}_{2}$ and $\mathrm{HPO}$, on the virulent strain of $B$. dermatitidis. A $0.1 \mathrm{M}$ concentration of $\mathrm{KCl}$ alone was not toxic to the virulent strain $(100 \%$ viable) as opposed to $100 \%$ lethality with $0.1 \mathrm{M}$ $\mathrm{KI}$. One problem in the interpretation of Howard's study, however, is the apparent decrease in viability of the fungus in the buffer over the 3$h$ incubation period. We have found that in the occasional experiment in which viability in buffer is $<90 \%$ of the initial inoculum (such experiments were not included in this report), the apparent toxicity of the various reagents is markedly enhanced, suggesting that other parameters, e.g., culture age, number of subcultures, and time the inoculum spent at room

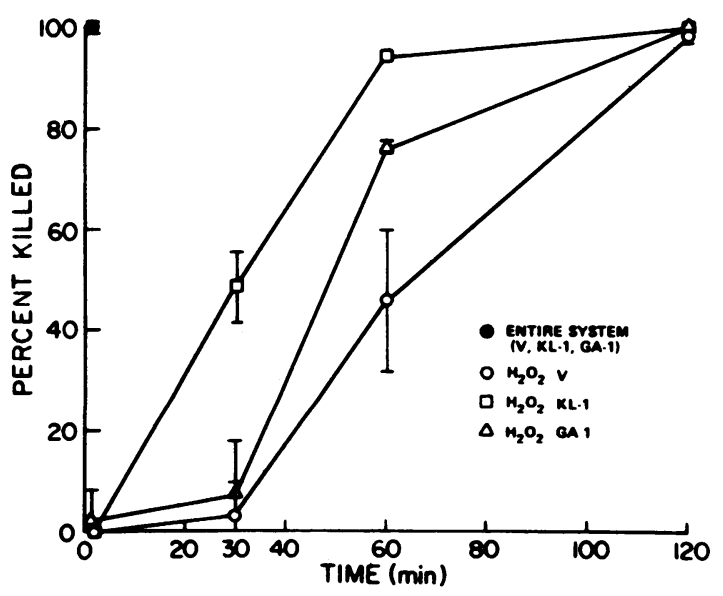

FIG. 2. Kinetics of killing of three strains of $B$. dermatitidis by $\mathrm{H}_{2} \mathrm{O}_{2}$. Concentrations of $\mathrm{H}_{2} \mathrm{O}_{2}$ were 5 $\times 10^{-2} \mathrm{M}$ for KL-1 and GA-1 and $10^{-1} \mathrm{M}$, for V. At 30 min, the results were significant for KL-1 versus GA-1 or V, $P<0.05$. At $60 \mathrm{~min}, \mathrm{~V}$ versus $\mathrm{GA}-1, P<0.05$; V versus $\mathrm{KL}-1, P<0.01 ; \mathrm{GA}-1$ versus $\mathrm{KL}-1, P<0.005$. temperature rather than at $37^{\circ} \mathrm{C}$, may affect fungal survival under study conditions such as these.

In the kinetic experiments, differences between the effects of $\mathrm{H}_{2} \mathrm{O}_{2}$ alone and in combination with $\mathrm{KI}$ and $\mathrm{PO}$ were evident. Killing of all three strains in the presence of $\mathrm{H}_{2} \mathrm{O}_{2}$ alone was time dependent and was only complete after 120 min of incubation. Killing of the virulent strain occurred most slowly, but in the continued presence of $\mathrm{H}_{2} \mathrm{O}_{2}$, killing was completed. However, the concentrations of $\mathrm{H}_{2} \mathrm{O}_{2}$ used in these kinetic experiments are above the physiological range (15), and their applicability to the in vivo situation is uncertain.

It is of interest that strains of $B$. dermatitidis which vary in virulence can also be differentiated in their ability to grow in prolonged cocultures with murine peritoneal macrophages (3). In this situation, the virulent strain escapes from the inhibition of its multiplication due to the coculturing with macrophages.

The observation that by 1 min of incubation all three strains of $B$. dermatitidis are killed by $\mathrm{H}_{2} \mathrm{O}_{2}$ in a physiological concentration (15) in the presence of $\mathrm{KI}$ and $\mathrm{PO}$ may be relevant to the in vivo situation. We have previously demonstrated that murine peritoneal macrophages activated by BCG or concanavalin A can kill the virulent strain of $B$. dermatitidis (4). Preliminary results also suggest that this killing can be abrogated by the presence of catalase (unpublished data). If $P O$ is involved in this killing, its source is unclear, since mature peritoneal macrophages are devoid of peroxidative activity (5). Heifets et al. (8) have indicated that exogenous PO, such as that from granulocytes, could provide the peritoneal macrophage with this activity and thus could facilitate killing of the fungus.

The lack of differences in susceptibility to the PPH system of the three strains of $B$. dermatitidis of different virulence for mice suggests that pathogen factors or other host factors, unrelated to products of oxidative metabolism as studied in our system, are important virulence factors.

\section{LITERATURE CITED}

1. Brass, C., C. M. Volkmann, H. P. Klein, C. J. Halde, R. W. R. Archibald, and D. A. Stevens. 1982. Pathogen factors and host factors in murine pulmonary blastomycosis. Mycopathologia 78:129-140.

2. Brass, C., C. M. Volkmann, D. E. Philpott, H. P. Klein, C. J. Halde, and D. A. Stevens. 1982. Spontaneous mutant of Blastomyces dermatitidis attenuated in virulence for mice. Sabouraudia 20:145-158.

3. Brummer, E., P. A. Morozumi, D. E. Philpott, and D. A. Stevens. 1981. Virulence of fungi: correlation of virulence of Blastomyces dermatitidis in vivo with escape from macrophage inhibition of replication in vitro. Infect. Immun. 32:864-871.

4. Brummer, E., A. M. Sugar, and D. A. Stevens. 1983. Activation of peritoneal macrophages by concanavalin A 
or Mycobacterium bovis BCG for fungicidal activity against Blastomyces dermatitidis and effect of specific antibody and complement. Infect. Immun. 39:817-822.

5. Daems, W. T., E. Wisse, P. Brederoo, and J. J. Emeis. 1973. Peroxidative activity in monocytes and macrophages, p. 57-77. In R. Van Furth (ed.), Mononuclear phagocytes in immunity, infection and pathology. Blackwell, London.

6. Decker, L. A. (ed.). 1977. Worthington enzyme manual. Worthington Biochemical Corp., Freehold, N.J.

7. Diamond, R. D., R. A. Clark, and C. C. Haudenschild. 1980. Damage to Candida albicans hyphae and pseudohyphae by the myeloperoxidase system and oxidative products of neutrophil metabolism in vitro. J. Clin. Invest. 66:908-917.

8. Heifets, L., K. Imai, and M. B. Goren. 1980. Expression of peroxidase-dependent iodination by macrophages ingesting neutrophil debris. J. Reticuloendothel. Soc. 28:391-404.

9. Howard, D. H. 1981. Comparative sensitivity of Histoplasma capsulatum conidiospores and blastospores to oxidative antifungal systems. Infect. Immun. 32:381-387.

10. Jackett, P. S., V. R. Aber, and D. B. Lowrie. 1978. Virulence of Mycobacterium tuberculosis and susceptibility to peroxidative killing systems. J. Gen. Microbiol. 107:273-278.
11. Klebanoff, S. J. 1968. Myeloperoxidase-halide-hydrogen peroxide antibacterial system. J. Bacteriol. 95:2131-2138.

12. Lehrer, R. I. 1975. The fungicidal mechanisms of human monocytes. I. Evidence for myeloperoxidase-linked and myeloperoxidase-independent candidacidal mechanisms. J. Clin. Invest. 55:338-346.

13. Murray, H. W., S. B. Aley, and W. A. Scott. 1981 Susceptibility of Entamoeba histolytica to oxygen intermediates. Mol. Biochem. Parasitol. 3:381-391.

14. Murray, H. W., and Z. A. Cohn. 1979. Macrophage oxygen dependent antimicrobial activity I. Susceptibility of Toxoplasma gondii to oxygen intermediates. J. Exp. Med. 150:939-949.

15. Nathan, C. F., C. H. Brukner, S. C. Silverstein, and Z. A. Cohn. 1979. Extracellular cytolysis by activated macrophages and granulocytes. I. Pharmacologic triggering of effector cells and the release of hydrogen peroxide. $J$. Exp. Med. 149:84-99.

16. Tsan, M.-F., K. H. Douglass, and P. A. McIntyre. 1977. Hydrogen peroxide production and killing of Staphylococcus aureus by human polymorphonuclear leukocytes. Blood 49:437-444.

17. Weiss, S. J., and A. Sliuka. 1982. Monocyte and granulocyte-mediated tumor cell destruction. A role for the hydrogen peroxide-myleperoxidase-chloride system. J. Clin. Invest. 69:255-262. 